\title{
Molecular characterization of antimicrobial resistance genes on farms and in commercial milk with emphasis on the effect of currently practiced heat treatments on viable but nonculturable formation
}

\author{
Eman M. Taher, ${ }^{1 *}$ Farhid Hemmatzadeh, ${ }^{2,3}$ Salwa A. Aly, ${ }^{1}$ Hamdy A. Elesswy, ${ }^{1}$ and Kiro R. Petrovski ${ }^{2,3,4}$ \\ ${ }^{1}$ Department of Food Hygiene and Control, Faculty of Veterinary Medicine, Cairo University, Giza 12211, Egypt \\ ${ }^{2}$ School of Animal and Veterinary Science, The University of Adelaide, Roseworthy, SA 5371, Australia \\ ${ }^{3}$ Australian Centre for Antimicrobial Resistance Ecology, School of Animal and Veterinary Sciences, The University of Adelaide, Waite Campus, \\ SA 5064, Australia \\ ${ }^{4}$ Davies Research Centre, School of Animal and Veterinary Sciences, The University of Adelaide, North Terrace Campus, SA 5005, Australia
}

\section{ABSTRACT}

Despite the considerable advances that have been made to improve dairy food safety, there is rising concern that pasteurization is not sufficient for the destruction of plasmid-mediated antimicrobial resistance (AMR) genes of resistant bacteria and could stimulate bacteria to enter into a viable but nonculturable (VBNC) state. In the current study, we surveyed the prevalence of 1 genomic and 9 plasmid-mediated AMR genes in 100 samples (bulk tank milk and milk filter socks) at the farm level and 152 commercial milk samples (pasteurized and UHT milks) and assessed the VBNC state in dairy bacteria. Results revealed that suld was the most prevalent plasmid-mediated gene in milk filter socks $(96 \%)$, bulk tank milk (48\%), pasteurized milk (68\%), and UHT (43\%) milk; in contrast, mecA was not detected in any sample. Additionally, commercial pasteurization (as currently practiced) failed to decrease the prevalence of the $b l a_{\text {TEM-B1 }}(43 \%)$, tetK $(30 \%)$, and tetA (55\%) plasmid-mediated AMR genes; thus, commercial pasteurization may be one of the factors creating the VBNC state in some dairy bacteria. Continued research is necessary to identify bacterial species entering the VBNC state after pasteurization, to assess their potential hazard level and shed more light on the expression and possibility of horizontal gene transfer of those plasmid-mediated AMR genes.

Key words: pasteurization, antimicrobial resistance gene, viable but nonculturable state, scanning electron microscopy, food safety

\footnotetext{
Received April 1, 2020.

Accepted June 8, 2020.

*Corresponding author: eman.taher@adelaide.edu.au or eman. elmaghraby@cu.edu.eg
}

\section{INTRODUCTION}

Milk is a high-quality food containing numerous essential nutrients; it not only plays a key role in helping humans meet their nutrient needs but also provides a medium for growth of wide range of spoilage and pathogenic microorganisms (Medhammar et al., 2012). Staphylococcus aureus, Streptococcus agalactiae, Streptococcus uberis, Streptococcus dysgalactiae, and Escherichia coli are considered the major pathogens causing mastitis and subclinical mastitis in dairy cattle, and these species have been shown to carry various genes associated with antimicrobial resistance (AMR; Rajeev et al., 2009; McDougall et al., 2014). The misuse and subinhibitory concentrations of antimicrobials on dairy farms, as part of the food chain, are assumed to be major factors responsible for the emergence and spread of AMR (Akindolire et al., 2015).

Mobile AMR genes are key elements in the rise and global spread of multidrug-resistant bacteria. These genes are commonly found on plasmids, circular, selfreplicating DNA pieces that facilitate the spread of newly emerged resistance determinants from products of animal origin to humans and their communities (Frost et al., 2005; Buckner et al., 2018; Cheng et al., 2019). In vivo transfer of antimicrobial resistance genes from foods to gut microbiota is still debatable, as it is theoretically acceptable and has been proved in vitro, but in vivo trials in milk and dairy products are lacking (Cheng et al., 2019); however, the risk of plasmidmediated AMR genes persisting in heat-treated milks cannot be ignored. An initial assessment would rely on the availability of information on the prevalence of the plasmid-mediated AMR genes at both the farm and commercial levels.

Important to ensuring milk safety for human consumption is milk being subjected to heat treatment (pasteurization or UHT treatment). High-temperature, short-time pasteurization is a validated heat treatment 
in the dairy industry that involves heating the milk to $72^{\circ} \mathrm{C}\left(161^{\circ} \mathrm{F}\right)$ for $15 \mathrm{~s}$. The aim of pasteurization is to reduce the number of microorganisms present, including pathogens, to a level where they do not pose a major consumer health risk (Mullan, 2019). Although pasteurization eliminates the majority of viable bacterial cells in good-quality raw milk (i.e., that with low initial thermoduric bacterial counts), it may also stimulate the formation of bacteria that are viable but nonculturable (VBNC; Yaniarti et al., 2017). Commercial UHT processing sterilizes the milk, killing not only viable bacteria but the majority of endospores as well; UHT processing usually involves heating milk to $>135^{\circ} \mathrm{C}$ for 2 to $5 \mathrm{~s}$. As such treatment is bactericidal, the VBNC state is not likely induced by UHT processing of milk.

The VBNC is a state induced when bacteria respond to harsh environmental stressors, such as pasteurization, by entering a novel physiological phase in which cells retain their viability and can express their virulence after resuscitation. As VBNC bacteria are not culturable in standard laboratory media, they pose a new challenge to food safety and public health (Wu et al., 2020). The in vitro occurrence of VBNC after milk pasteurization has been studied previously $(\mathrm{Gu}-$ nasekera et al., 2002) but, to the best of our knowledge, this study is the first to investigate commercial heat treatments as a potential factor inducing the VBNC state in dairy bacteria. The objective of this study was to survey the prevalence of plasmid-mediated AMR genes on milk filters and in bulk tank milk at the farm level and the persistence of AMR genes after commercial heat treatments (pasteurization and UHT), and to assess the possible creation of the VBNC state in dairy bacteria.

\section{MATERIALS AND METHODS}

\section{Sample Collection}

Fifty bulk tank milks (BTM) and 50 milk filter socks (MFS) were collected aseptically in sterile 100$\mathrm{mL}$ containers from dairy farms in the south east of South Australia and western Victoria, Australia. Samples were placed in refrigerated coolers at $4^{\circ} \mathrm{C}$ and delivered immediately to the laboratory. Concurrently, 152 commercial milk samples-84 pasteurized (commercially pasteurized milk; $72^{\circ} \mathrm{C}$ for $15 \mathrm{~s}$ ) and $68 \mathrm{UHT}$ samples - were purchased from commercial suppliers in Adelaide, South Australia. Commercial suppliers were chosen based on which milk processor the dairy farms of interest supplied. Samples were kept refrigerated and sent to the laboratory immediately. Molecular and microbiologic testing of the samples were done in parallel.

\section{Molecular Identification}

DNA Extraction. Each BTM, MFS, pasteurized, and UHT sample was prepared following previously reported protocols (Van Kessel et al., 2011; Giacometti et al., 2012). Briefly, $2 \mathrm{~mL}$ of each sample was centrifuged at $8,000 \times g$ for $20 \mathrm{~min}$ and supernatant fat and excess liquid were removed by siphoning. Extraction of DNA was carried out on the skimmed milk part using the QIAMP DNA extraction kit (Qiagen, Venlo, the Netherlands) following the manufacturer's instructions. The DNA concentration was measured using a Nanodrop 1000c spectrophotometer (Thermo Fisher Scientific Inc., Waltham, MA) and stored at $-20^{\circ} \mathrm{C}$ until further use.

PCR Probes and Protocol for Identification of Bacteria. A previously published adapted PCR protocol using 16S rRNA species-specific probes for screening of E. coli, staphylococci, and streptococci were used (Table 1; Malhotra-Kumar et al., 2005; Lange et al., 2015; Rahman et al., 2017). The PCR amplification was conducted following a previously adopted protocol (Taher et al., 2020). Briefly, the $25-\mu \mathrm{L}$ total volume contained $0.5 \mu \mathrm{L}$ of Taq DNA polymerase $(5 \mathrm{U} / \mu \mathrm{L}$; Bio-line, Boston, MA), $5 \mu \mathrm{L}$ of $5 \times$ reaction buffer (Bio-line), $1 \mu \mathrm{L}(0.5 \mu M)$ of each forward and reverse primer, $2 \mu \mathrm{L}$ of extracted DNA template, and $15.5 \mu \mathrm{L}$ of diethyl pyrocarbonate-treated water. Amplifications were performed in 35 cycles, using a T100 Thermal Cycler (Bio-Rad Thermocycler, Hercules, CA), consisting of preheating activation for $10 \mathrm{~min}$ at $94^{\circ} \mathrm{C}$, denaturation at $94^{\circ} \mathrm{C}$ for $30 \mathrm{~s}$, annealing at $60^{\circ} \mathrm{C}$ (for $E$. coli) or $66^{\circ} \mathrm{C}$ (for Staphylococcus and Streptococcus spp. primers), with extension at $72^{\circ} \mathrm{C}$ for $1 \mathrm{~min}$. The final extension step was performed at $72^{\circ} \mathrm{C}$ for $10 \mathrm{~min}$. The amplification products were resolved by electrophoresis in $1.5 \%$ agarose gels, visualized by staining with Gel Red (Biotium, Wembley, Australia), and photographed.

Molecular Detection of AMR Genes. An adapted PCR protocol using 10 gene-specific primers for bla $a_{\text {TEM-1B }}, b l a Z, \operatorname{erm} B, \operatorname{erm} C, \operatorname{mec} A$, mecC, sul2, tetA, tet $M$, and tet $K$ genes was used (Table 1; MalhotraKumar et al., 2005; Dallenne et al., 2010; Pyatov et al., 2017; Taher et al., 2020). Control positive strains included Staph. aureus (ATCC BAA-2312) for the mecC gene; Staphylococcus sciuri (a strain previously isolated and whole-genome sequenced by our group; Khazandi et al., 2018) for the blaZ, ermC, mecA, and tetK genes; Streptococcus gallolyticus (clinical isolate) for the ermB and tet $M$ genes; and multidrug-resistant E. coli ST131 (clinical isolate) for the $t e t A$, bla $a_{\mathrm{TEM}-1 \mathrm{~B}}$, and suld genes.

A previously described (Taher et al., 2020) PCR amplification was performed in 35 cycles, as detailed 


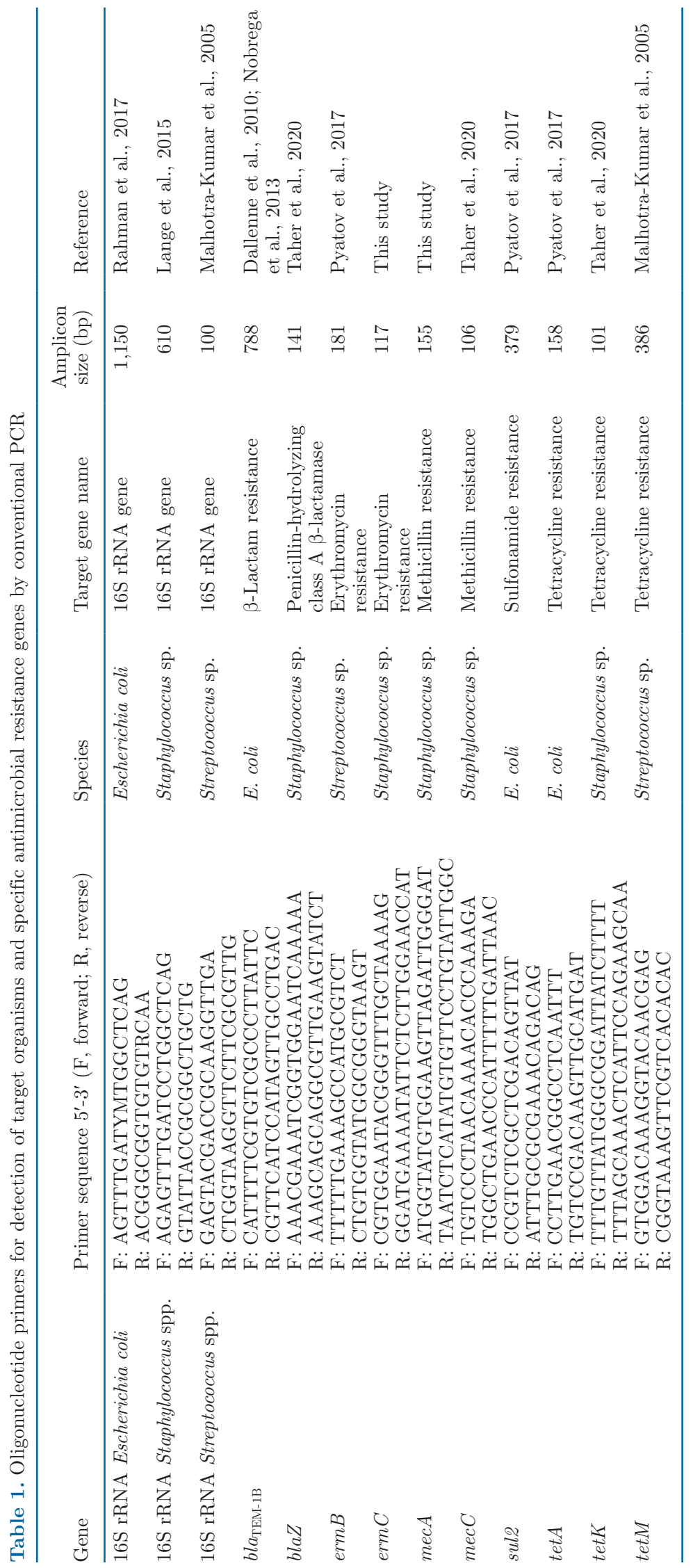


above, with annealing at $67^{\circ} \mathrm{C}$ for $b l a_{\mathrm{TEM}-1 \mathrm{~B}}$ and sul2; $65^{\circ} \mathrm{C}$ for blaZ and tet $A ; 60^{\circ} \mathrm{C}$ for mec $C$, tet $M$, tetK, and $m e c A ; 66^{\circ} \mathrm{C}$ for $\mathrm{ermB}$; and $62^{\circ} \mathrm{C}$ for erm $C$. The final extension step was performed at $72^{\circ} \mathrm{C}$ for $10 \mathrm{~min}$. The amplification products were resolved by electrophoresis in 1.5 and $2.5 \%$ agarose gels, visualized by staining with Gel Red, and photographed.

Microbial Cultures and MALDI-TOF Identification. Pasteurized and UHT milk samples were conventionally cultivated by inoculating $100 \mu \mathrm{L}$ onto duplicate plate count agar and sheep blood agar (general media for aerobic plate counts; Columbia, Thermo Scientific), MacConkey agar (for total coliform count), Brilliance Escherichia coli agar (for E. coli identification), and mannitol salt agar plates (for isolation of Staphylococcus spp.; all media from Oxoid, Basingstoke, UK; Hayes et al., 2001). Plates were incubated at $37^{\circ} \mathrm{C}$ for 24 to $48 \mathrm{~h}$. To determine the purity of colonies with preliminary growth, they were transferred onto sheep blood agar. Species identification (Ngassam Tchamba et al., 2019) was carried out by the direct transfer approach with $\alpha$-cyano-4-hydroxycinnamic acid as a matrix using MALDI-TOF MS (Autoflex Biotyper Mass Spectrometer, Bruker, Germany), following the manufacturer's instructions. If no peak was detected, the sample was rerun using the extended direct transfer approach, either on target formic acid treatment or full ethanol-formic acid extraction, following the manufacturer's guidelines. The spectra were analyzed with MBT Compass Software (Bruker Daltonik GmbH, Bremen, Germany), supported by Windows 7; only score-values between 2.00 and 3.00 (green) were considered further.

\section{Detection of VBNC State}

Light Microscopy Screening. Pasteurized and UHT milk samples were cleared through enzymatic treatment with $0.05 \mathrm{mg}$ of proteinase K (Sigma-Aldrich, Sydney, Australia; Gunasekera et al., 2000; Taher et al., 2020). Samples were then centrifuged for $10 \mathrm{~min}$ at $14,000 \times g$, and lipids (top layer) and digested proteins of the milk were removed without disturbing the bacteria-containing pellet. The pellet was resuspended in $100 \mu \mathrm{L}$ of $150 \mathrm{mM} \mathrm{NaCl}$, and $5 \mu \mathrm{L}$ of suspension was trapped between a coverslip and glass slide. Bacteria were imaged using the $60 \times$ objective and brightfield mode on an Olympus BX51 microscope (Olympus, Tokyo, Japan) and videos were recorded (Supplemental Video Files S1 and S2; https://doi.org/10.3168/jds .2020-18631).

Live/Dead Confocal Fluorescent Microscopy Scanning. Samples were treated enzymatically and stained as previously described (Taher et al., 2020) us- ing the BacLight LIVE/DEAD assay (Thermo Fisher Scientific Inc.). Bacteria were then examined using confocal fluorescent microscopy (FV3000 confocal microscope, Olympus) with laser excitation at $488 \mathrm{~nm}$, emission detection at 500 to $600 \mathrm{~nm}$ for (Syto Green) live stain, and, for both live and dead staining, laser excitation at $514 \mathrm{~nm}$, emission detection at 613 to 713 $\mathrm{nm}$ with $10 \times$ and $60 \times$ objectives.

Scanning Electron Microscopy. Samples were treated enzymatically as described in the previous step, following (Taher et al., 2020), to enable distinguishing bacteria during electron microscopy. Samples were then fixed overnight with $1.25 \%$ glutaraldehyde and $4 \%$ paraformaldehyde in PBS containing $4 \%$ sucrose. Thereafter, samples were washed in PBS, fixed for $1 \mathrm{~h}$ in $1 \%$ osmium tetroxide, and dehydrated in an ascending ethanol series from $50 \%$ (vol/vol) to absolute ethanol. Samples were chemically dried (Tousimis Critical Point Dryer 931, Thermo Fisher Scientific) using hexamethyldisilazane and mounted on aluminum stubs, sputter coated with $5 \mathrm{~nm}$ platinum, and examined using a Philips XL 30 FESEM scanning electron microscope (Thermo Fisher Scientific).

\section{Statistical Analysis}

All statistical analyses were carried out using SAS version 9.4 (SAS Institute Inc., Cary, NC). Mean prevalence, standard errors of the means, confidence limits, and normality of distribution were calculated using PROC MEANS and PROC FREQ. Differences between prevalence of various samples (filter sock, bulk tank, pasteurized, or UHT) were calculated using PROC GLM.

\section{RESULTS AND DISCUSSION}

The objectives of this study were to measure the effect of the currently practiced heat treatment of commercial milk (pasteurization and UHT) on the prevalence of plasmid-mediated AMR genes in milk and at the farm level as a first step in evaluating their potential hazard level in heat-treated milk. Additionally, we qualitatively estimated the effect of pasteurization as a stress factor predisposing to creation of the VBNC state in common dairy pathogenic bacteria.

We attempted to compare BTM with corresponding commercial milk samples. Despite our efforts, due to sourcing of the commercial milks from local shops and not directly from the dairy processing plant, BTM and commercial milk samples could not be entirely matched. In future studies, with cooperation by the dairy industry, milks for testing should be strictly 
matched. However, this limitation does not decrease the importance of the study as these BTM were related to the dairy processor and the general supply of the commercial milk tested.

\section{Effect of Commercial Heat Treatment on Presence of Bacteria}

At the farm level, PCR detection of the $16 \mathrm{~S}$ rDNA of 3 bacteria showed that their prevalence in MFS samples were 64, 100, and $94 \%$ for E. coli, Staphylococcus spp., and Streptococcus spp., respectively, whereas their prevalence in representative BTM samples were 58,72 , and $68 \%$, respectively. This decrease from MFS to BTM underlines the importance of milk filtration at the farm level as a first step to decrease the prevalence of such bacteria and subsequently their potential antimicrobial resistance genes. These findings were similar to those of published reports (Murphy et al., 2005, 2010; Rola et al., 2015). Nevertheless, commercially pasteurized and UHT milks showed a high prevalence of E. coli (61.9 and 29.4\%), Staphylococcus spp. (86.9 and $67.6 \%$ ), and Streptococcus spp. (95.5 and 80.9\%), respectively (Table 2). Detection of $16 \mathrm{~S}$ rDNA to evaluate the prevalence of such bacteria is the first step in their molecular characterization. Further studies are essential for their complete characterization and identification and to assess their potential hazard level from the food safety perspective.

\section{Effect of Heat Treatment on AMR Genes}

Despite numerous antimicrobial susceptibility studies of microbial pathogens, few data describe the prevalence and levels of plasmid-mediated AMR genes in raw and heat-treated cow milk. Estimation of the prevalence of plasmid-mediated AMR genes in both farm and commercial milk is the primary step for understanding the process of antimicrobial-mediated selection and the possible horizontal gene transmission of AMR genes from milk in future studies.

At the farm level, the most prevalent AMR genes were sul2 (96 and $48 \%$ prevalence in MFS and BTM, respectively), tetK (62 and 30\%), tetA (80 and 44\%), ermB (66 and 22\%), bla TEM-1B $(54$ and $24 \%$ ), respectively, whereas mecA was not detected in any of the samples (Table 2), which supports the previous findings (Virgin et al., 2009; Haran et al., 2012). The higher prevalence levels in MFS samples indicated that the filters reduced the microorganisms detectable in BTM after filtration. This finding is of great importance for the dairy industry and supports the use of high-quality milk filters at the farm level to ensure lower initial microbial count, and thus decreased presence of AMR genes, in the BTM.

In commercial milks, a high prevalence of sul2 (67.9 and $42.6 \%$ ), tetA (54.8 and $27.9 \%$ ), tetM (31 and $26.5 \%)$, and $b a_{\text {TEM-1B }}(42.9$ and $32.4 \%)$ was detected in pasteurized and UHT milks, respectively, similar to results in a previous report (Chopra and Roberts, 2001; Table 2). The presence of these genes is likely a result of the use of corresponding antimicrobials at the farm level. In Australia, the most frequently used antimicrobials are aminoglycosides, $\beta$-lactams, macrolides, sulfonamides, and tetracycline. However, despite the high use of $\beta$-lactams, blaZ (3.6 and 5.8\%) and mecC (2.3 and 2.9\%) had low prevalence in pasteurized and UHT milks, respectively, and mecA was not

Table 2. Prevalence (\% and 95\% CI) of $16 \mathrm{~S}$ genes of target organisms and 10 antimicrobial resistance genes in filter socks (n $=50$ samples), bulk tank milk $(\mathrm{n}=50)$, pasteurized milk $(\mathrm{n}=84)$, and UHT milk samples $(\mathrm{n}=68)$

\begin{tabular}{|c|c|c|c|c|}
\hline Gene & \multicolumn{4}{|c|}{ Type of sample } \\
\hline Staphylococcus spp. & $100.0(99.02-100.81)$ & $72.0(59.11-84.88)$ & $86.9(79.53-94.26)$ & $67.7(56.23-79.05)$ \\
\hline Streptococcus spp. & $94.0(87.18-100.81)$ & $68.0(54.60-81.39)$ & $95.5(90.58-99.88)$ & $80.9(71.29-90.47)$ \\
\hline \multicolumn{5}{|c|}{ Antimicrobial resistance genes $(\%)$} \\
\hline $\mathrm{erm} B$ & $66.0(52.40-79.59)$ & $22.0(10.10-38.92)$ & $14.3(6.64-21.91)$ & $17.6(8.35-26.94)$ \\
\hline $\mathrm{erm} C$ & $10.0(1.38-18.61)$ & 0.0 & $7.2(1.53-12.91)$ & $14.7(6.06-23.34)$ \\
\hline mecA & 0.0 & 0.0 & 0.0 & 0.0 \\
\hline mecC & $8.0(0.21-15.78)$ & $2.0(0.00-3.49)$ & $2.4(0.00-11.24)$ & $2.9(0.00-7.06)$ \\
\hline sul2 & $96.0(90.37-100.16)$ & $48.0(33.65-62.34)$ & $67.9(57.66-78.05)$ & $42.6(30.58-54.70)$ \\
\hline tet $A$ & $80.0(68.51-91.48)$ & $44.0(29.74-58.25)$ & $54.8(43.89-65.62)$ & $27.9(16.99-38.88)$ \\
\hline tetK & $62.0(48.06-75.93)$ & $30.0(16.84-43.15)$ & $4.8(0.11-9.41)$ & $16.2(7.19-25.15)$ \\
\hline
\end{tabular}




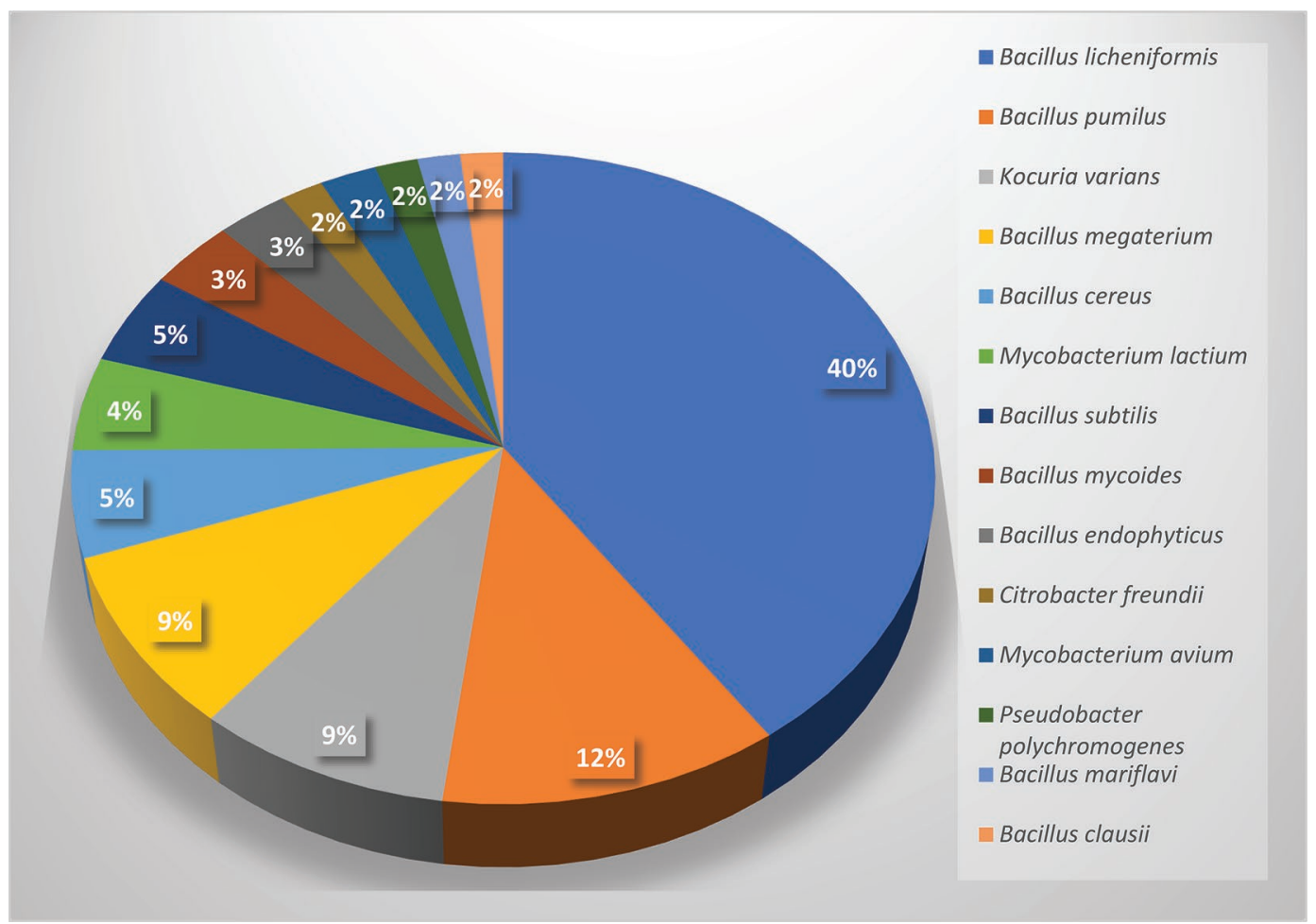

Figure 1. Bacterial isolates from the pasteurized milk samples identified by MALDI-TOF MS.

detected. Although numerous studies have investigated the prevalence of AMR at the farm level (Berge et al., 2007; Virgin et al., 2009; Haran et al., 2012; Obaidat et al., 2018), evaluation of the prevalence of the plasmidmediated AMR genes in heat-treated milk is lacking.

\section{Culturing and MALDI-TOF Species Identification}

Culture on sheep blood agar showed no growth in all examined UHT samples, but colonies were present on all cultured pasteurized milk samples. The MALDITOF MS analysis revealed that 138 colonies $(80.7 \%)$ were Bacillus spp., 6 (3.5\%) were Enterobacteriaceae, $15(8.8 \%)$ were Kocuria varians, and $12(7 \%)$ were Mycobacterium spp. (Figure 1). This finding confirmed that UHT treatment (i.e., commercial sterilization) of milk was sufficient to kill almost all viable bacteria and most endospores in tested UHT milk samples, comparatively to other studies, which showed some highly heat-resistant sporeformers (i.e., Bacillus sporothermodurans) in UHT milk (Tabit and Buys, 2011). Although pasteurization killed most viable bacteria, as expected, microbial endospores remained and could germinate thereafter. The low prevalence $(3.5 \%)$ of Enterobacteriaceae (Citrobacter and Pseudobacterspp.) could indicate post-pasteurization contamination, as reported by Masiello et al. (2016). The low prevalence of Enterobacteriaceae could support previous studies, which indicate that Enterobacteriaceae could be a post-pasteurization contaminant (Hanson et al., 2005; Sarkar, 2015; Ngassam Tchamba et al., 2019). No E. coli, staphylococci, or streptococci were detected by routine microbial culture of pasteurized milk on either specific or general media.

\section{Potential Effect of Milk Heat Treatment on VBNC Formation}

Pasteurization temperature is one of the adverse environmental conditions thought to be a predisposing factor for the VBNC state in different microorganisms (Fakruddin et al., 2013). Given that pasteurization time and temperature are not sufficient to destroy all Staphylococcus spp. producing enterotoxins, recommending treatment at $80^{\circ} \mathrm{C}$ for 20 min for complete elimination of those staphylococci may be required (Yaniarti et al., 2017). Furthermore, pasteurization has been described as a predisposing factor for VBNC creation in E. coli in milk and dairy products (Gunasekera et al., 2002). Thus, currently practiced heat treatments in the dairy sector need to be investigated for their potential to induce the VBNC state. 

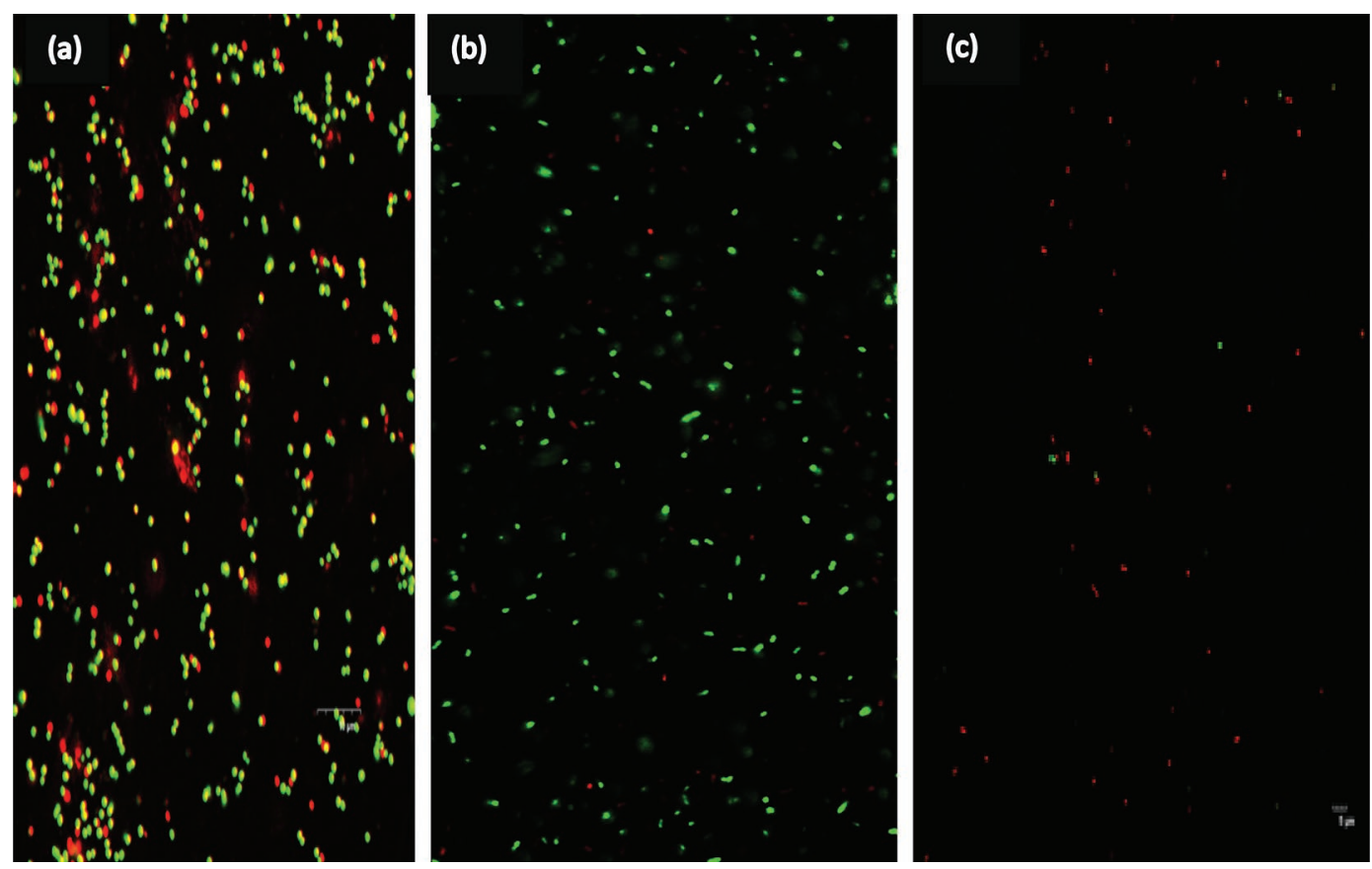

Figure 2. Confocal laser scanning microscopy after LIVE/DEAD (ThermoFisher Scientific Inc., Waltham, MA) staining of (a) positive control sample (Staphylococcus aureus ATCC BAA-231), (b) pasteurized milk sample, and (c) UHT milk sample; the green fluorescence (cocci and bacilli) represents live or viable but nonculturable (VBNC) bacteria, and the red fluorescence represents dead bacteria.

\section{Detection of Different Bacterial Population with Light Microscopy}

Cultures of pasteurized and UHT milk samples on different media showed growth in most of the tested pasteurized samples. Identification of the cultured isolates by MALDI-TOF determined that almost all were Bacillus spp. (>80\%). This finding was not unexpected because bacilli form endospores. The culture results coupled with $16 \mathrm{~S}$ rDNA results for the 3 tested genera of bacteria indicated that bacteria might be present but not detected by culture (i.e., in a VBNC state). Thus, milk samples were examined by light microscopy (Supplemental Video Files S1 and S2; https:// doi.org/10.3168/jds.2020-18631). Microscopy indicated the presence of different types of bacterial populations (e.g., bacilli, coccobacilli, and cocci) with a variety of movements of those cocci and bacilli against the fluid's Brownian motion. These findings confirmed our suspicion that some of the detected bacteria had lost their culturability but remained viable. Further studies are required to complete identification and differentiation of those microorganisms.

\section{Live/Dead Staining Assay}

On assessment with the Live/Dead staining assay, both fluorescent dyes (red and green) were detected.
The assay allows differentiation of cells based on membrane integrity, using 2 nucleic acid fluorescent stains, SYTO 9 (green) and propidium iodide (red). Using dual staining, dead bacteria with disrupted membranes fluoresce red, whereas live bacteria fluoresce green (Figure 2). Similar to results from light microscopy, the BacLight LIVE/DEAD assay detected different shapes of live cells (e.g., bacilli and cocci). The frequency of detection of live bacteria was higher in pasteurized milk than in UHT milk samples. The VBNC state and the thermal resistance of staphylococci have been reported previously (Kennedy et al., 2005; Zandri et al., 2012). Our findings indicated that the UHT treatment more efficiently killed VBNC dairy bacteria.

\section{Electron Microscopy Screening of the Microbial Population}

Electron microscopy of pasteurized and UHT milk samples detected 2 intact bacterial cell types (i.e., bacilli and cocci), and the frequency of the cocci was higher in pasteurized than in UHT milk samples (Figure 3). We expected to find bacilli, but the intact cocci need further identification to determine whether they are pathogenic or nonpathogenic VBNC bacteria (e.g., staphylococci or streptococci).

The results of both viability assessment and scanning electron microscopy indicate the potential creation of 

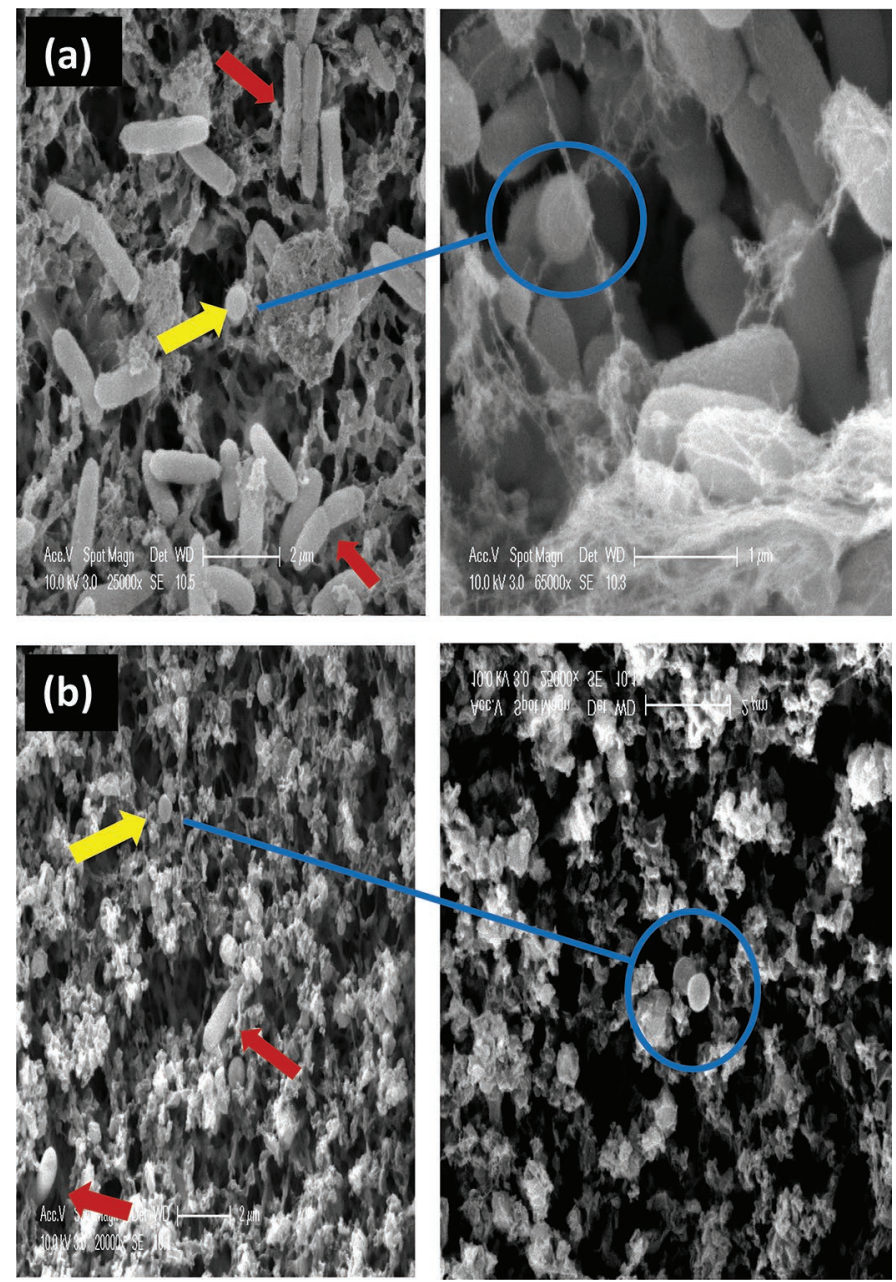

Figure 3. Scanning electron micrographs showing intact bacterial shapes of bacilli (red arrows) and cocci (yellow arrows) in (a) pasteurized, and (b) UHT milk samples. The scale bars represent $2 \mu \mathrm{m}$. The blue-circled coccus in the right-hand panel is the same as that indicated by the yellow arrow in the left-hand panel but in a different plane and at a higher magnification, to better demonstrate the presence of intact cocci.

the VBNC state in dairy bacteria (Oliver, 2010), which poses a potential threat to food safety because milk and dairy products can no longer be considered free from pathogens, even when routine cultures are negative. With the aim of evaluating the potential hazard of VBNC bacteria in milk after commercial pasteurization, we recommend further morphological identification and resuscitation studies.

\section{CONCLUSIONS}

We found that commercially heat-treated milk, especially pasteurized milk, demonstrated high prevalence of different plasmid-mediated AMR genes. Our results revealed the persistence of live intact bacterial cell types (i.e., rods and cocci), different from Bacillus species, which might be in a VBNC state as an adaptive response to pasteurization temperature. The VBNC state and potential resuscitation of VBNC bacteria under suitable conditions pose a potential hazard to the dairy processing industry and consumers. Further studies are needed to estimate hazard levels of plasmid-mediated AMR genes and their possible horizontal transfer, as well as the risk associated with VBNC bacteria originating from pasteurized milk.

\section{ACKNOWLEDGMENTS}

We express our great appreciation to Ken Lee, Rebel Skirving, Tania Veltman, Verity Coombe, and Terang Veterinary Clinic (Terang, VIC, Australia) for their valuable assistance on this project. Cynthia Bottema (School of Animal and Veterinary Science, the University of Adelaide, Roseworthy, SA, Australia) is thanked for reviewing the manuscript and English corrections. This research was supported by the University of Adelaide and Cultural Affairs and Mission Sector, Ministry of Higher Education, Egypt. EMT contributed to project conceptualization, data curation, formal analysis, investigation, methodology, project administration, resources, software, data analysis, and writing (original draft). FH, SAA, and HAE contributed to project conceptualization, supervision, and writing (reviewing and editing). KRP contributed to project conceptualization, data analysis, funding acquisition, supervision, and writing (reviewing and editing). The authors have not stated any conflicts of interest.

\section{REFERENCES}

Akindolire, M., O. Babalola, and C. Ateba. 2015. Detection of antibiotic resistant Staphylococcus aureus from milk: A public health implication. Int. J. Environ. Res. Public Health 12:10254-10275. https://doi.org/10.3390/ijerph120910254.

Berge, A. C. B., S. C. Champagne, R. M. Finger, and W. M. Sischo. 2007. The use of bulk tank milk samples to monitor trends in antimicrobial resistance on dairy farms. Foodborne Pathog. Dis. 4:397-407. https://doi.org/10.1089/fpd.2007.0009.

Buckner, M. M. C., M. L. Ciusa, and L. J. V. Piddock. 2018. Strategies to combat antimicrobial resistance: Anti-plasmid and plasmid curing. FEMS Microbiol. Rev. 42:781-804. https://doi.org/10.1093/ femsre/fuy031.

Cheng, G., J. Ning, S. Ahmed, J. Huang, R. Ullah, B. An, H. Hao, M. Dai, L. Huang, X. Wang, and Z. Yuan. 2019. Selection and dissemination of antimicrobial resistance in agri-food production. Antimicrob. Resist. Infect. Control 8:158. https://doi.org/10.1186/ s13756-019-0623-2.

Chopra, I., and M. Roberts. 2001. Tetracycline antibiotics: Mode of action, applications, molecular biology, and epidemiology of bacterial resistance. Microbiol. Mol. Biol. Rev. 65:232-260. https://doi.org/ 10.1128/MMBR.65.2.232-260.2001 
Dallenne, C., A. Da Costa, D. Decre, C. Favier, and G. Arlet. 2010. Development of a set of multiplex PCR assays for the detection of genes encoding important beta-lactamases in Enterobacteriaceae. J. Antimicrob. Chemother. 65:490-495. https://doi.org/10.1093/ $\mathrm{jac} / \mathrm{dkp} 498$.

Fakruddin, M., K. S. B. Mannan, and S. Andrews. 2013. Viable but nonculturable bacteria: Food safety and public health perspective. ISRN Microbiol. 2013:703813. https://doi.org/10.1155/2013/ 703813.

Frost, L. S., R. Leplae, A. O. Summers, and A. Toussaint. 2005. Mobile genetic elements: The agents of open source evolution. Nat. Rev. Microbiol. 3:722-732. https://doi.org/10.1038/nrmicro1235.

Giacometti, F., A. Serraino, G. Finazzi, P. Daminelli, M. N. Losio, P. Bonilauri, N. Arrigoni, A. Garigliani, R. Mattioli, S. Alonso, S. Piva, D. Florio, R. Riu, and R. G. Zanoni. 2012. Foodborne pathogens in in-line milk filters and associated on-farm risk factors in dairy farms authorized to produce and sell raw milk in northern Italy. J. Food Prot. 75:1263-1269. https://doi.org/10.4315/0362 -028X.JFP-12-028.

Gunasekera, T. S., P. V. Attfield, and D. A. Veal. 2000. A flow cytometry method for rapid detection and enumeration of total bacteria in milk. Appl. Environ. Microbiol. 66:1228-1232. https://doi.org/ 10.1128/aem.66.3.1228-1232.2000.

Gunasekera, T. S., A. Sorensen, P. V. Attfield, S. J. Sorensen, and D. A. Veal. 2002. Inducible gene expression by nonculturable bacteria in milk after pasteurization. Appl. Environ. Microbiol. 68:19881993. https://doi.org/10.1128/aem.68.4.1988-1993.2002.

Hanson, M. L., W. L. Wendorff, and K. B. Houck. 2005. Effect of heat treatment of milk on activation of Bacillus spores. J. Food Prot. 68:1484-1486. https://doi.org/10.4315/0362-028x-68.7.1484.

Haran, K. P., S. M. Godden, D. Boxrud, S. Jawahir, J. B. Bender, and S. Sreevatsan. 2012. Prevalence and characterization of Staphylococcus aureus, including methicillin-resistant Staphylococcus aureus, isolated from bulk tank milk from Minnesota dairy farms. J. Clin. Microbiol. 50:688-695. https://doi.org/10.1128/JCM.05214 -11 .

Hayes, M. C., R. D. Ralyea, S. C. Murphy, N. R. Carey, J. M. Scarlett, and K. J. Boor. 2001. Identification and characterization of elevated microbial counts in bulk tank raw milk. J. Dairy Sci. 84:292-298. https://doi.org/10.3168/jds.S0022-0302(01)74479-7.

Kennedy, J., I. S. Blair, D. A. McDowell, and D. J. Bolton. 2005. An investigation of the thermal inactivation of Staphylococcus aureus and the potential for increased thermotolerance as a result of chilled storage. J. Appl. Microbiol. 99:1229-1235. https://doi.org/ 10.1111/j.1365-2672.2005.02697.x.

Khazandi, M., A. A.-B. Al-Farha, G. W. Coombs, M. O'dea, S. Pang, D. J. Trott, R. R. Aviles, F. Hemmatzadeh, H. Venter, A. D. Ogunniyi, A. Hoare, S. Abraham, and K. R. Petrovski. 2018. Genomic characterization of coagulase-negative staphylococci including methicillin-resistant Staphylococcus sciuri causing bovine mastitis. Vet. Microbiol. 219:17-22. https://doi.org/10.1016/j.vetmic .2018.04.004.

Lange, C. C., M. A. V. P. Brito, D. R. L. Reis, M. A. Machado, A. S. Guimarães, A. L. S. Azevedo, É. B. Salles, M. C. T. Alvim, F. S. Silva, and I. R. Meurer. 2015. Species-level identification of staphylococci isolated from bovine mastitis in Brazil using partial $16 \mathrm{~S}$ rRNA sequencing. Vet. Microbiol. 176:382-388. https://doi .org/10.1016/j.vetmic.2015.01.024.

Malhotra-Kumar, S., C. Lammens, J. Piessens, and H. Goossens. 2005. Multiplex PCR for simultaneous detection of macrolide and tetracycline resistance determinants in streptococci. Antimicrob. Agents Chemother. 49:4798-4800. https://doi.org/10.1128/AAC .49.11.4798-4800.2005.

Masiello, S. N., N. H. Martin, A. Trmčić, M. Wiedmann, and K. J. Boor. 2016. Identification and characterization of psychrotolerant coliform bacteria isolated from pasteurized fluid milk. J. Dairy Sci. 99:130-140. https://doi.org/10.3168/jds.2015-9728.

McDougall, S., H. Hussein, and K. Petrovski. 2014. Antimicrobial resistance in Staphylococcus aureus, Streptococcus uberis and Strep- tococcus dysgalactiae from dairy cows with mastitis. N. Z. Vet. J. 62:68-76. https://doi.org/10.1080/00480169.2013.843135.

Medhammar, E., R. Wijesinha-Bettoni, B. Stadlmayr, E. Nilsson, U. R. Charrondiere, and B. Burlingame. 2012. Composition of milk from minor dairy animals and buffalo breeds: A biodiversity perspective. J. Sci. Food Agric. 92:445-474. https://doi.org/10.1002/ jsfa.4690.

Mullan, W. M. A. 2019. Are we closer to understanding why viable cells of Mycobacterium avium ssp. paratuberculosis are still being reported in pasteurised milk? Int. J. Dairy Technol. 72:332-344. https://doi.org/10.1111/1471-0307.12617.

Murphy, B. P., M. Murphy, J. F. Buckley, D. Gilroy, M. T. Rowe, D. McCleery, and S. Fanning. 2005. In-line milk filter analysis: Escherichia coli $\mathrm{O} 157$ surveillance of milk production holdings. Int. J. Hyg. Environ. Health 208:407-413. https://doi.org/10.1016/j .ijheh.2005.03.001.

Murphy, B. P., E. O'Mahony, J. F. Buckley, S. O'brien, and S. Fanning. 2010. Characterization of Staphylococcus aureus isolated from dairy animals in Ireland. Zoonoses Public Health 57:249-257. https://doi.org/10.1111/j.1863-2378.2008.01220.x.

Ngassam Tchamba, C., A. S. Rao, F. Boyen, F. Haesebrouck, J. N. Duprez, L. Théron, D. Thiry, and J. G. Mainil. 2019. Comparison of quantitative PCR and MALDI-TOF mass spectrometry assays for identification of bacteria in milk samples from cows with subclinical mastitis. J. Appl. Microbiol. 127:683-692. https://doi.org/ 10.1111/jam.14358.

Nobrega, D., M. Guiduce, F. Guimaraes, D. Riboli, M. Cunha, H. Langoni, J. Pantoja, and S. B. Lucheis. 2013. Molecular epidemiology and extended-spectrum beta-lactamases production of Klebsiella pneumoniae isolated from three dairy herds. Pesqui. Vet. Bras. $33: 855-859$.

Obaidat, M. M., A. Bani Salman, and A. Roess. 2018. High prevalence and antimicrobial resistance of mecA Staphylococcus aureus in dairy cattle, sheep, and goat bulk tank milk in Jordan. Trop. Anim. Health Prod. 50:405-412. https://doi.org/10.1007/s11250 $-017-1449-7$.

Oliver, J. D. 2010. Recent findings on the viable but nonculturable state in pathogenic bacteria. FEMS Microbiol. Rev. 34:415-425. https://doi.org/10.1111/j.1574-6976.2009.00200.x.

Pyatov, V., I. Vrtková, and A. Knoll. 2017. Detection of selected antibiotic resistance genes using multiplex PCR assay in mastitis pathogens in the Czech Republic. Acta Vet. Brno 86:167-174. https://doi.org/10.2754/avb201786020167.

Rahman, M. M., K. B. Yoon, S. J. Lim, M. G. Jeon, H. J. Kim, H. Y. Kim, J. Y. Cho, H. M. Chae, and Y. C. Park. 2017. Molecular detection by analysis of the $16 \mathrm{~S}$ rRNA gene of fecal coliform bacteria from the two Korean Apodemus species (Apodemus agrarius and $A$. peninsulae). Genet. Mol. Res. 16:gmr16029510. https://doi.org/10 .4238/gmr16029510.

Rajeev, N. K., S. Isloor, D. Rathnamma, and N. B. Shridhar. 2009. Characterization of Staphylococcus aureus and E. coli of bovine mastitis. Indian Vet. J. 86:883-885.

Rola, J. G., W. Korpysa-Dzirba, A. Czubkowska, and J. Osek. 2015. Prevalence of enterotoxin genes and antimicrobial resistance of coagulase-positive staphylococci recovered from raw cow milk. J. Dairy Sci. 98:4273-4278. https://doi.org/10.3168/jds.2014-9064.

Sarkar, S. 2015. Microbiological considerations: Pasteurized milk. Int. J. Dairy Sci 10:206-218. https://doi.org/10.3923/ijds.2015.206 218 .

Tabit, F. T., and E. M. Buys. 2011. Incidence and survival of Bacillus sporothermodurans during processing of UHT milk. Br. Food J. 113:505-518. https://doi.org/10.1108/00070701111123989.

Taher, E. M., F. Hemmatzadeh, S. A. Aly, H. A. Elesswy, and K. R. Petrovski. 2020. Survival of staphylococci and transmissibility of their antimicrobial resistance genes in milk after heat treatments. LWT 129:109584. https://doi.org/10.1016/j.lwt.2020.109584.

Van Kessel, J. A. S., J. S. Karns, J. E. Lombard, and C. A. Kopral. 2011. Prevalence of Salmonella enterica, Listeria monocytogenes, and Escherichia coli virulence factors in bulk tank milk and in-line 
filters from U.S. dairies. J. Food Prot. 74:759-768. https://doi .org/10.4315/0362-028X.JFP-10-423.

Virgin, J. E., T. M. Van Slyke, J. E. Lombard, and R. N. Zadoks. 2009 Short communication: Methicillin-resistant Staphylococcus aureus detection in US bulk tank milk. J. Dairy Sci. 92:4988-4991. https: //doi.org/10.3168/jds.2009-2290.

Wu, D., F. Forghani, E. B.-M. Daliri, J. Li, X. Liao, D. Liu, X. Ye, S. Chen, and T. Ding. 2020. Microbial response to some nonthermal physical technologies. Trends Food Sci. Technol. 95:107-117. https://doi.org/10.1016/j.tifs.2019.11.012.
Yaniarti, M. N., C. Amarantini, and T. Y. Budiarso. 2017. The effect of temperature and pasteurization time on Staphylococcus aureus isolates from dairy products. AIP Conf. Proc. 1908:050003. https: //doi.org/10.1063/1.5012727.

Zandri, G., S. Pasquaroli, C. Vignaroli, S. Talevi, E. Manso, G. Donelli, and F. Biavasco. 2012. Detection of viable but non-culturable staphylococci in biofilms from central venous catheters negative on standard microbiological assays. Clin. Microbiol. Infect. 18:E259261. https://doi.org/10.1111/j.1469-0691.2012.03893.x. 